\title{
Analysis of natural radioactivity in Yatağan coal - fired power plant in Turkey
}

\author{
Aydan Altıkulaç ${ }^{1}$, Şeref Turhan ${ }^{2}$ and Hasan Gümüş ${ }^{3}$ \\ ${ }^{1}$ Muğla Sitkı Koçman University, Ula Ali Koçman MYO, Department of Electricity and Energy, Muğla, Turkey \\ ${ }^{2}$ Kastamonu University, Faculty of Sciences and Art, Department of Physics, Kastamonu, Turkey \\ ${ }^{3}$ Ondokuzmayıs University, Faculty of Sciences and Art, Department of Physics, Samsun, Turkey
}

\begin{abstract}
Use of the coal in order to generate electricity increases the exposure of people to radiation. In this paper, the activity concentrations of nuclides ${ }^{226} \mathrm{Ra},{ }^{232} \mathrm{Th}$ and ${ }^{40} \mathrm{~K}$ in samples of coal and bottom ash from the Yatagan Coal-Fired thermal power plant determined using gamma ray spectrometer with a $\mathrm{NaI}(\mathrm{Tl})$ scintillation detector. The mean activity concentrations of ${ }^{226} \mathrm{Ra},{ }^{232} \mathrm{Th}$, and ${ }^{40} \mathrm{~K}$ in the coal were found to be $37.2 \pm 2.8 \mathrm{Bqkg}^{-1}, 51.8 \pm 3.4 \mathrm{Bqkg}^{-1}$ and $166.7 \pm 11.1 \mathrm{Bqkg}^{-1}$, respectively. Whereas in the bottom ashes, the concentrations of the corresponding radionuclides were found to be $62.2 \pm 5.6 \mathrm{Bqkg}^{-1}, 87.4 \pm 5.9$ $\mathrm{Bqkg}^{-1}$ and $221.0 \pm 12.5 \mathrm{Bqkg}^{-1}$, respectively. The findings show that bottom ashes show higher activity concentrations of related radionuclide to coal samples. The absorbed gamma dose rate in outdoor air $\mathrm{DR}_{\text {OUT }}$ and annual effective dose rate (AED) from coal were calculated to define radiological risk. The average findings of annual effective doses were detected as $68.6 \pm 5.1 \mu \mathrm{Svy}^{-1}$ and $110.3 \pm 11.2 \mu \mathrm{Svy}^{-1}$, respectively.
\end{abstract}

\section{Introduction}

Energy is one of the most important inputs to the economic and social development of a country. Much of the energy needed in the world is met by fossil sources such as coal and natural gas. The most important share of fossil energy resources in Turkey belongs to the coal mine. According to World Energy Council statistics, world coal reserves freeze to 861 billion ton [1]. About $1.7 \%$ of the world's coal reserves are in Turkey. Coal is used as fuel in coal operated power plants to generated electricity in Turkey. Coal and lignite fueled thermal power plants in Turkey reported total electricity generation of $90.335 \mathrm{GWh}$ per year. In the composition of fuels such as coal, there are fewer or more natural radioactive substances, such as ${ }^{226} \mathrm{Ra},{ }^{210} \mathrm{Po}$ and ${ }^{210} \mathrm{~Pb}$, as well as ${ }^{40} \mathrm{~K}$, derived from ${ }^{238} \mathrm{U}$ and ${ }^{232} \mathrm{Th}$. The uranium and other radioisotopes in the lignite coal burned at high temperatures in thermal power plants becomes enrich and passes to the ash. Part of the heavy ash falls down to the bottom of the furnace as "bottom ash" together with unburned organic matter, while light ashes are transported along with hot gases to the pail and form fly ash. The average activity concentrations of ${ }^{226} \mathrm{Ra},{ }^{232} \mathrm{Th}$ and ${ }^{40} \mathrm{~K}$ in coal according to UNSCEAR are 20, 20 and $50 \mathrm{Bqkg}^{-1}$, respectively [2-4]. The fly ash formed by burning the coal causes the radioactive materials to spread in the atmosphere. A large proportion of the radioactivity is remains in the bottom ash after combustion. About $0.5-2 \%$ of the total ash resulting from the fly ash combustion is released to the atmosphere and this event creates a potential risk for the very close environment of the coal fired power plant [5]. The amount of coal required to produce $1 \mathrm{GWh}$ of electricity per year is $3 \times 10^{9} \mathrm{~kg}$. As a result, the radioactive pollution given to the atmosphere per year is $4000 \mathrm{MBq}$ for ${ }^{40} \mathrm{~K}, 1500 \mathrm{MBq}$ for ${ }^{238} \mathrm{U}$ through ${ }^{226} \mathrm{Ra}$, $5000 \mathrm{MBq}$ for ${ }^{210} \mathrm{~Pb}$ and ${ }^{210} \mathrm{Po}$ and $1500 \mathrm{MBq}$ for the radionuclides of ${ }^{232} \mathrm{Th}$ decay series, from ${ }^{232} \mathrm{Th}$ to ${ }^{224} \mathrm{Ra}$. As well as there are the ash mountains that generate atmospheres ${ }^{222} \mathrm{Rn}$ around each coal -fired power plant. Especially radioactive radon $\left({ }^{222} \mathrm{Rn}\right)$ gas and short-lived decay products $\left({ }^{214} \mathrm{Bi}\right.$ of ${ }^{214} \mathrm{~Pb}$ etc.) can be taken into the body through the respiratory tract and increase the risk of cancer by damaging the lung tissue [6]. In this study, the activities of natural radioactive elements were determined in the samples of coal and bottom ash.

\section{Material and method}

\subsection{Preparing samples for measurement}

Yatağan Thermal Power Plant has $3 \times 210 \mathrm{MW}$ power is located in Muğla, which has a significant portion of Turkey's lignite reserves [7]. In this paper, radioactivity measurements were made in the samples of bottom ash generated by burning of coal and coal used as fuel in Yatağan Thermal Power Plant. All samples were dried for one day in the oven at a preheated of 100 degrees. The dried samples were put in standard vessels and the mass and date of creation were recorded. Each sample vessel was wrapped with parafilm to provide a seal. ${ }^{226} \mathrm{Ra}$ 
and ${ }^{232} \mathrm{Th}$ in all samples were expected to reach a radioactive equilibrium for a month.

\subsection{Gamma measurements}

Gamma spectrometric measurements of ${ }^{226} \mathrm{Ra},{ }^{232} \mathrm{Th}$ and ${ }^{40} \mathrm{~K}$ in the samples were carried out by the agency of scintillation gamma-ray spectrometer with a sodium iodide (NaI) detector. The calibration of the detector performed using photo peaks from radioactive standards IAEA- RGU-1, IAEA-RGTh-1 and IAEA-RGK-1 reference materials. The detector has an energy resolution of $46 \mathrm{keV}$ at $622 \mathrm{keV}{ }^{137} \mathrm{Cs}$. The ${ }^{226} \mathrm{Ra}$ activity of the samples was detected by means of the density of $351.9 \mathrm{keV}$ and $609.3 \mathrm{keV}$ gamma lines of ${ }^{214} \mathrm{~Pb}$ and ${ }^{214} \mathrm{Bi}$, respectively. ${ }^{232} \mathrm{Th}$ activity was acquired through the gamma publisher of ${ }^{228} \mathrm{Ac}$ at $911.21 \mathrm{keV} .{ }^{40} \mathrm{~K}$ concentration was directly read from spectrum analysis results. Spectrum analyzes were carried out using the ScintiVision gamma ray software.

\section{Result and discussion}

\subsection{Activity concentration}

The activity concentrations of ${ }^{226} \mathrm{Ra},{ }^{232} \mathrm{Th}$ and ${ }^{40} \mathrm{~K}$ were calculated for 20 different coal and 20 different bottom ash sample. The results for coal samples are shown in Table 1 . As seen in Table 1, the activity concentrations of ${ }^{226} \mathrm{Ra}^{232} \mathrm{Th}$ and ${ }^{40} \mathrm{~K}$ were measured as $37.2 \pm 2.8 \mathrm{Bqkg}^{-}$ ${ }^{1}$, (range from 26 to 47 ), $51.8 \pm 3.4 \mathrm{Bqkg}^{-1}$, (range from 19 to 80 ) and $166.7 \pm 11.1 \mathrm{Bqkg}^{-1}$ (range from 137 to 189 ), respectively. The measured radioactivity and related radiological parameters in the bottom ash are as in Table 2. So, it can be said that bottom ashes show higher activity concentrations of related radionuclide to coal samples. The data obtained is higher than the data in UNSCEAR report $[2,3]$.

\subsection{Equivalent radium activity}

This parameter is calculated by multiplying the corresponding radioactive elements by different coefficients and this calculation is shown in the following Equation [8,9].

$$
R a_{e q}=A_{R a}+\frac{10}{7} A_{T h}+\frac{10}{130}
$$

Where $A_{R a}, A_{T h}$ and $A_{K}$ are the activities of ${ }^{226} \mathrm{Ra},{ }^{232} \mathrm{Th}$ and ${ }^{40} \mathrm{~K}$, respectively. As seen in Table 1 and Table 2, the equivalent activities calculated for bottom ash are about twice that of coal. Where $A_{R a}, A_{T h}$ and $A_{K}$ are the activities of ${ }^{226} \mathrm{Ra},{ }^{232} \mathrm{Th}$ and ${ }^{40} \mathrm{~K}$, respectively.

As seen in Table 1 and Table 2, the equivalent activities calculated for bottom ash are about twice that of coal.
Table 1. Activity concentrations and calculated gamma doses in coal samples

\begin{tabular}{|c|c|c|c|c|c|}
\hline Sample ID & $\begin{array}{c}{ }^{226} \mathrm{Ra} \\
\left(\mathrm{Bqkg}^{1}\right)\end{array}$ & $\begin{array}{c}{ }^{232} \mathrm{Th} \\
\left.\mathrm{Bqkg}_{-}{ }^{1}\right)\end{array}$ & $\begin{array}{c}{ }^{40} \mathrm{~K} \\
\left(\mathrm{Bqkg}^{-1}\right)\end{array}$ & $\begin{array}{l}\mathrm{Ra}_{\mathrm{eq}} \\
\left(\mathrm{Bqkg}^{1}\right)\end{array}$ & $\begin{array}{c}\text { External } \\
\text { absorbed } \\
\text { gamma } \\
\text { dose } \mathrm{D}_{\mathrm{R}} \\
\left(\mathrm{nGyh}^{-1}\right)\end{array}$ \\
\hline $\mathrm{C2}$ & $29 \pm 2$ & $19 \pm 1$ & $178 \pm 11$ & $68 \pm 6$ & $32 \pm 2$ \\
\hline C3 & $49 \pm 4$ & $40 \pm 3$ & $168 \pm 10$ & $118 \pm 9$ & $54 \pm 4$ \\
\hline C4 & $37 \pm 2$ & $23 \pm 1$ & $186 \pm 12$ & $83 \pm 6$ & $39 \pm 3$ \\
\hline C5 & $36 \pm 2$ & $48 \pm 3$ & $162 \pm 10$ & $115 \pm 8$ & $53 \pm 4$ \\
\hline C6 & $40 \pm 3$ & $52 \pm 3$ & $189 \pm 13$ & $128 \pm 9$ & $58 \pm 4$ \\
\hline C7 & $45 \pm 4$ & $57 \pm 4$ & $169 \pm 11$ & $138 \pm 10$ & $63 \pm 5$ \\
\hline C8 & $39 \pm 3$ & $53 \pm 3$ & $137 \pm 10$ & $124 \pm 9$ & $56 \pm 4$ \\
\hline C9 & $36 \pm 3$ & $46 \pm 3$ & $144 \pm 10$ & $111 \pm 9$ & $51 \pm 4$ \\
\hline $\mathrm{C} 10$ & $47 \pm 3$ & $60 \pm 4$ & $180 \pm 12$ & $145 \pm 11$ & $66 \pm 5$ \\
\hline C11 & $32 \pm 2$ & $45 \pm 3$ & $168 \pm 11$ & $108 \pm 8$ & $49 \pm 3$ \\
\hline C12 & $36 \pm 3$ & $48 \pm 3$ & $156 \pm 11$ & $115 \pm 8$ & $53 \pm 4$ \\
\hline C13 & $38 \pm 2$ & $51 \pm 3$ & $173 \pm 11$ & $125 \pm 9$ & $56 \pm 4$ \\
\hline $\mathrm{C} 14$ & $40 \pm 3$ & $54 \pm 3$ & $188 \pm 12$ & $130 \pm 10$ & $59 \pm 4$ \\
\hline C15 & $35 \pm 2$ & $69 \pm 4$ & $154 \pm 10$ & $144 \pm 12$ & $65 \pm 5$ \\
\hline C16 & $39 \pm 2$ & $77 \pm 5$ & $172 \pm 11$ & $160 \pm 13$ & $73 \pm 5$ \\
\hline $\mathrm{C} 17$ & $40 \pm 3$ & $75 \pm 4$ & $171 \pm 11$ & $158 \pm 12$ & $72 \pm 5$ \\
\hline C18 & $40 \pm 4$ & $80 \pm 4$ & $137 \pm 9$ & $163 \pm 12$ & $74 \pm 6$ \\
\hline C19 & $26 \pm 2$ & $49 \pm 3$ & $180 \pm 12$ & $97 \pm 8$ & $50 \pm 3$ \\
\hline $\mathrm{C2O}$ & $33 \pm 2$ & $54 \pm 3$ & $153 \pm 10$ & $120 \pm 9$ & $51 . \pm 4$ \\
\hline Average & $37 \pm 2$ & $51 \pm 3$ & $166 \pm 11$ & $121 \pm 9$ & $56 \pm 4$ \\
\hline
\end{tabular}

\subsection{Calculation of gamma doses}

The gamma dose taken in the air $\left(D_{R}\right)$ at a height of $1 \mathrm{~m}$ from the ${ }^{226} \mathrm{Ra},{ }^{232} \mathrm{Th}$, and ${ }^{40} \mathrm{~K}$ found in the structure of the material was calculated by the following Equation [10].

$$
D\left(n G y h^{-1}\right)=0.462 A_{R a}+0.623 A_{T h}+0.0414 A_{K}
$$

where $A_{R a}, A_{T h}$ and $A_{K}$ are the activity concentrations of ${ }^{226} \mathrm{Ra},{ }^{232} \mathrm{Th}$, and ${ }^{40} \mathrm{~K}$ in $\mathrm{Bqkg}^{-1}$, respectively. External absorbed gamma dose rate calculated for coal and bottom ash samples are shown in Table 1 and Table 2 . The calculated average value for coal is $56.9 \pm 4.4 \mathrm{nGyh}^{-1}$ while the calculated value for bottom ash is $90.8 \pm 6.5$ $\mathrm{nGyh}^{-1}$. The dose rate in airdoors from terrestrial gamma rays in normally is around $60 \mathrm{nGyh}^{-1}$, with the mean range from 10 to $200 \mathrm{nGyh}^{-1}$, according to the UNSCEAR 2000 report [11].

The calculated results for coal and bottom ash samples are $68.6 \pm 5.1$ and $110.3 \pm 11.2 \mu \mathrm{Svy}^{-1}$, respectively. According to the UNSCEAR 2000 report, this value was announced as $70 \mu \mathrm{Svy}^{-1}$ for the world average [11]. It can be said that the mean value calculated for coal is around the world average. But the mean value for bottom ash is above the world average. 
Table 2. Activity concentrations and calculated gamma doses in bottom ash samples.

\begin{tabular}{|c|c|c|c|c|c|}
\hline Sample ID & $\begin{array}{c}{ }^{226} \mathrm{Ra} \\
\left(\mathrm{Bqkg}_{-}{ }^{1}\right)\end{array}$ & $\begin{array}{c}{ }^{232} \mathrm{Th} \\
\left(\mathrm{Bqkg}_{-}{ }^{1}\right)\end{array}$ & $\begin{array}{c}{ }^{40} \mathrm{~K} \\
\left(\mathrm{Bqkg}^{-1}\right)\end{array}$ & $\begin{array}{l}\mathrm{Ra}_{\mathrm{eq}} \\
\left(\mathrm{Bqkg}^{-1}\right)\end{array}$ & $\begin{array}{l}\text { External } \\
\text { absorbed } \\
\text { gamma } \\
\text { dose } D_{\mathrm{R}} \\
\left(\mathrm{nGyh}^{-1}\right)\end{array}$ \\
\hline BA1 & $47 \pm 3$ & $34 \pm 2$ & $241 \pm 14$ & $112 \pm 6$ & $53 \pm 3$ \\
\hline BA2 & $48 \pm 3$ & $50 \pm 3$ & $239 \pm 14$ & $136 \pm 8$ & $62 \pm 4$ \\
\hline BA3 & $60 \pm 5$ & $49 \pm 3$ & $250 \pm 14$ & $148 \pm 8$ & $74 \pm 4$ \\
\hline BA4 & $64 \pm 6$ & $76 \pm 5$ & $267 \pm 15$ & $191 \pm 11$ & $87 \pm 5$ \\
\hline BA5 & $74 \pm 6$ & $99 \pm 6$ & $220 \pm 12$ & $230 \pm 12$ & $103 \pm 7$ \\
\hline BA6 & $65 \pm 5$ & $84 \pm 6$ & $204 \pm 12$ & $200 \pm 11$ & $89 \pm 6$ \\
\hline BA7 & $63 \pm 5$ & $86 \pm 6$ & $172 \pm 9$ & $197 \pm 11$ & $88 \pm 6$ \\
\hline BA8 & $68 \pm 5$ & $92 \pm 6$ & $203 \pm 11$ & $213 \pm 12$ & $95 \pm 6$ \\
\hline BA9 & $60 \pm 5$ & $80 \pm 5$ & $176 \pm 10$ & $187 \pm 10$ & $83 \pm 5$ \\
\hline BA10 & $59 \pm 4$ & $77 \pm 5$ & $191 \pm 11$ & $183 \pm 10$ & $81 \pm 5$ \\
\hline BA11 & $59 \pm 4$ & $79 \pm 5$ & $202 \pm 11$ & $186 \pm 10$ & $84 \pm 6$ \\
\hline BA12 & $72 \pm 6$ & $98 \pm 6$ & $194 \pm 10$ & $226 \pm 13$ & $100 \pm 7$ \\
\hline BA13 & $70 \pm 6$ & $93 \pm 6$ & $227 \pm 13$ & $219 \pm 12$ & $98 \pm 7$ \\
\hline BA14 & $59 \pm 4$ & $76 \pm 5$ & $253 \pm 14$ & $185 \pm 11$ & $83 \pm 5$ \\
\hline BA15 & $71 \pm 6$ & $132 \pm 8$ & $237 \pm 13$ & $276 \pm 13$ & $122 \pm 8$ \\
\hline BA16 & $58 \pm 3$ & $112 \pm 7$ & $256 \pm 14$ & $249 \pm 14$ & $105 \pm 7$ \\
\hline BA17 & $50 \pm 3$ & $96 \pm 6$ & $219 \pm 12$ & $202 \pm 12$ & $90 \pm 6$ \\
\hline BA18 & $55 \pm 3$ & $115 \pm 7$ & $234 \pm 13$ & $235 \pm 13$ & $104 \pm 7$ \\
\hline BA19 & $62 \pm 5$ & $104 \pm 6$ & $216 \pm 12$ & $225 \pm 12$ & $100 \pm 7$ \\
\hline BA20 & $74 \pm 6$ & $117 \pm 7$ & $227 \pm 12$ & $256 \pm 14$ & $114 \pm 8$ \\
\hline Average & $62 \pm 5$ & $87 \pm 5$ & $221 \pm 12$ & $200 \pm 11$ & $90 \pm 6$ \\
\hline
\end{tabular}

\section{Conclusions}

Muğla is located in Turkey, where has a significant portion of lignite reserves, and, ${ }^{226} \mathrm{Ra},{ }^{232} \mathrm{Th}$, and ${ }^{40} \mathrm{~K}$ radioisotopes are naturally found in these lignite coals by various measurements. The purpose of this study is to make measurements of natural radioactivity in samples of coal and bottom as samples taken from Yatağan CoalFired Power Plant basin in Muğla. The results show that the natural radioactivity of the bottom ash is about 2 times that of the coal natural radioactivity and this is an expected result. It can be said that the concentrations of radium, thorium and potassium in coal and bottom ash samples are slightly above the world average in the finds obtained.

\section{References}

1. World Energy Concil, Survey of Energy Resources, London. (2010)

2. UNSCEAR Ionizing Radiaiton: Sources and biological effects. United Nations Scientific Commitee on the Effects of Atomic Radiaiton, United Naitons, New York. (1982)

3. UNSCEAR Ionizing Radiaiton:Sources and biological effects. United Nations Scientific Commitee on the Effects of Atomic Radiaiton, United Naitons, New York. (1988)

4. Gür. F, and Günseli. Y, Journal of Environmental Science and Health, Part A. 45, 1900-1908 (2010)

5. Bem, H., Wieczorrkowski, P., Budzanowski, M, J. Environ. Radioact. 61, 191-201 (2002)

6. Aycik, G.A, and Ercan, A, J. Environ. Radioact. 35, 23-35 (1997)

7. Akyüz. T, Akyüz. S, Varinlioğlu. A, Köse. A, Eric. J, Davies. D, Spectroscopy Letters. 29, 1131-1139 (1996)

8. Turhan. Ş, Arıkan. I.H, Yücel. B, Varinlioğlu. A., Köse. A, Fuel. 89, 2528-2535 (2010)

9. Beretka. J, Mathew. P.J, Health Phys, 48, 87-95 (1985)
10. Kurnaz. A, Gezelge. M, Hançerlioğulları. A, Çetiner. M.A Turhan. Ş, Human and Ecological Risk Assessment: An International Journal. 22, 1375-1385 (2016)

11. UNSCEAR (2000) Ionizing Radiaiton: Sources and biological effects. United Nations Scientific Commitee on the Effects of Atomic Radiaiton, United Naitons, New York. 